\title{
Global scenarios of irrigation water abstractions for bioenergy production: a systematic review
}

\author{
Fabian Stenzel $^{1,2,3,4}$, Dieter Gerten ${ }^{1,2,3}$, and Naota Hanasaki ${ }^{5}$ \\ ${ }^{1}$ Potsdam Institute for Climate Impact Research (PIK), Member of the Leibniz Association, \\ P.O. Box 6012 03, 14412 Potsdam, Germany \\ ${ }^{2}$ Department of Geography, Humboldt-Universität zu Berlin, \\ Unter den Linden 6, 10099 Berlin, Germany \\ ${ }^{3}$ Integrative Research Institute on Transformations of Human-Environment Systems (IRI THESys), \\ Humboldt-Universität zu Berlin, 10099 Berlin, Germany \\ ${ }^{4}$ Water program, International Institute for Applied Systems Analysis (IIASA), Schlossplatz 1, 2361 Laxenburg, Austria \\ ${ }^{5}$ Center for Climate Change Adaptation, National Institute for Environmental Studies, \\ 16-2 Onogawa, Tsukuba, Ibaraki 305-8506, Japan
}

Correspondence: Fabian Stenzel (stenzel@pik-potsdam.de)

Received: 2 July 2020 - Discussion started: 6 July 2020

Revised: 18 January 2021 - Accepted: 31 January 2021 - Published: 6 April 2021

\begin{abstract}
Many scenarios of future climate evolution and its anthropogenic drivers include considerable amounts of bioenergy as a fuel source, as a negative emission technology, and for providing electricity. The associated freshwater abstractions for irrigation of dedicated biomass plantations might be substantial and therefore potentially increase water limitation and stress in affected regions; however, assumptions and quantities of water use provided in the literature vary strongly. This paper reviews existing global assessments of freshwater abstractions for bioenergy production and puts these estimates into the context of scenarios of other wateruse sectors. We scanned the available literature and (out of 430 initial hits) found 16 publications (some of which include several bioenergy-water-use scenarios) with reported values on global irrigation water abstractions for biomass plantations, suggesting water withdrawals in the range of 128.4 to $9000 \mathrm{~km}^{3} \mathrm{yr}^{-1}$, which would come on top of (or compete with) agricultural, industrial, and domestic water withdrawals. To provide an understanding of the origins of this large range, we present the diverse underlying assumptions, discuss major study differences, and calculate an inverse water-use efficiency (iwue), which facilitates comparison of the required freshwater amounts per produced biomass harvest. We conclude that due to the potentially high water demands and the tradeoffs that might go along with them,
\end{abstract}

bioenergy should be an integral part of global assessments of freshwater demand and use. For interpreting and comparing reported estimates of possible future bioenergy water abstractions, full disclosure of parameters and assumptions is crucial. A minimum set should include the complete water balances of bioenergy production systems (including partitioning of blue and green water), bioenergy crop species and associated water-use efficiencies, rainfed and irrigated bioenergy plantation locations (including total area and meteorological conditions), and total biomass harvest amounts. In the future, a model intercomparison project with standardized parameters and scenarios would be helpful.

\section{Introduction}

Previous assessments of global green and blue water requirements of a potential widespread bioenergy industry show a large variation in the estimates (withdrawals of 128.4$9000 \mathrm{~km}^{3} \mathrm{yr}^{-1}$; De Fraiture et al., 2008; Hejazi et al., 2014), while there is still insufficient analysis of the underlying sources of variation and assumptions that need to be standardized.

Projections of future energy demand and its partitioning increasingly assume replacement of carbon-intense fossil en- 
ergy carriers with biomass, which could provide carbonneutral electricity or fuels (Nakićenović et al., 1998; Rose et al., 2014; Bauer et al., 2018). However, in order to limit mean global warming to $2^{\circ} \mathrm{C}$ or even $1.5^{\circ} \mathrm{C}$ (UNFCCC, 2015), technologies providing additional negative emissions (NEs) are potentially needed to compensate for residual and past emissions (Rockström et al., 2017; Minx et al., 2018; Rogelj et al., 2018). One such NE technology (NET) is bioenergy with carbon capture and storage (BECCS). Bioenergy utilizes plant photosynthetic capacity to make available energy from sunlight in biomass, whereby $\mathrm{CO}_{2}$ is extracted from the atmosphere but at the same time water is transferred from soil to the atmosphere in the process of evapotranspiration. Due to the large amount of potentially needed NEs in the second half of the century (e.g. $3.3 \mathrm{GtC} \mathrm{yr}^{-1}$ reported by Smith et al., 2016 and 2-5 GtC yr${ }^{-1}$ reported by Rogelj et al., 2015), the feedstock is projected to be grown on large managed plantations and include substantial irrigation, demanding tradeoffs between negative emissions and area requirements as well as water consumption to be solved sustainably.

Suggested energy carriers for BECCS are either energyrich plant organs (e.g. rapeseed, oil palms, sugarcane) to be directly converted to biofuels (first-generation bioenergy) or lignocellulosic biomass from fast-growing plants such as maize, Miscanthus, switchgrass, willows, or Eucalyptus (Yuan et al., 2008; Soccol et al., 2016), i.e. second-generation bioenergy. These diverse plants have different growth rates, preferred climatic zones, and - depending on the location where they are projected to be grown - different freshwater demands (King et al., 2013).

While burning of fossil energy carriers leads to (net positive) emissions of greenhouse gases, use of biomass is net neutral apart from land-use and process-chain emissions (AlAnsari et al., 2017). Thus, use of bioenergy can offset other carbon-intensive means of energy generation, such as coal, gas, or oil (Gough et al., 2018; Fajardy and Mac Dowell, 2017). To provide respective NEs, bioenergy use needs to be complemented by means of carbon storage. Proposed methods include pyrogenic carbon capture and storage (PyCCS; Werner et al., 2018; Schmidt et al., 2019), BECCS (Azar et al., 2006; Lenton, 2010), or other long-term storage preventing a release of the captured carbon back to the atmosphere. For a comprehensive analysis of carbon capture technologies, see for example Markewitz et al. (2012).

Bioenergy plantations (BPs) can be either completely rainfed or partially irrigated. Plantations of the former type would completely depend on "green" precipitation water stored in soils, while the latter additionally include more or less pronounced use of "blue" water from lakes, rivers, reservoirs, and aquifers (Hoekstra et al., 2009; Fader et al., 2011; Wang et al., 2017).

The discussion for or against large-scale irrigation of BPs revolves around a set of economic and sustainability tradeoffs, requiring a more comprehensive quantification of water use of bioenergy systems. The required high biomass produc- tivity for reaching ambitious climate targets might promote irrigation to reduce land requirement tradeoffs with, e.g. food production. This however would happen at the expense of freshwater ecosystems (Poff and Zimmerman, 2010) and human societies in terms of increased overall water stress (Schewe et al., 2014) or lead to unwanted modification of terrestrial water cycling (Vervoort et al., 2009). Additional investment in irrigation systems would be required (Hogan et al., 2007), which might, however, become economically feasible due to an increased value of biomass through carbon pricing (Bauer et al., 2018). Li et al. (2018) report at least $15 \%$ (and potentially much more due to most studies not reporting this parameter) of field experiments with lignocellulosic bioenergy crops to be irrigated.

Additionally, the process chain from biomass to NEs requires water as well but has rarely been quantified (e.g. in Smith et al., 2016). This might be because large-scale CCS is not yet in place and the process of conversion to energy and subsequent long-term storage is usually not modelled in detail by the existing models. One exception is Fajardy et al. (2018), who also include polluted ("grey") water from the biomass processing chain.

Review studies on the potentials of BECCS and other NE technologies (e.g. Creutzig et al., 2015; Smith et al., 2016 and Fuss et al., 2018), have so far not provided a comprehensive overview of the associated freshwater abstractions (besides their precursory mentioning).

The suggested large quantities of blue water withdrawals and/or consumptions assumed for BP irrigation in the literature, which may occur in competition with other water uses and may increase water stress in relatively water-scarce regions where BPs are considered, motivate a comprehensive understanding and quantification of their intrinsic water requirements (Hejazi et al., 2015; Wada et al., 2014). Thus, the subject of the present paper is to fill this knowledge gap and systematically review the current literature on projected freshwater abstractions in global NE or energy scenarios relying on BECCS or bioenergy. Additionally, we illustrate how such global scale syntheses could be standardized in data requirements and formats, analytical frameworks, scopes of inference, supporting assumptions, and reconciliation across spatio-temporal scales.

The analysis is guided by the following questions:

1. What are the key modelling parameters and assumptions of global bioenergy studies that affect the inherent water demand projections? (Sect. 3.1 and 3.2)

2. What are the global freshwater abstractions for irrigation of bioenergy plantations in the future as projected in available global-scale studies? (Sect. 3.3)

3. How do amounts of freshwater abstractions for irrigated biomass plantations compare to other sectors? (Sect. 3.4) 
4. Is there a dependence between the simulated freshwater abstractions and the total global biomass production across studies? (Sect. 3.5)

The resulting literature corpus consists of 16 publications containing a total of 34 scenarios. In principle one could also include local or regional studies, but their numbers cannot be straightforwardly upscaled or compared with the global studies due to a lack of site-specific data for plantation locations in global studies. We separate quantities of blue water application on BPs into withdrawals (gross extraction from rivers, lakes, reservoirs) or consumption (eventual evapotranspiration, excluding return flows to the rivers and water bodies that may occur after withdrawal). Existing studies are then compared regarding (a) the total global water volume quantified as a component of the hydrologic cycle and (b) the global mean water-use efficiency per biomass produced (iwue (inverse water-use efficiency) - the water abstractions per biomass produced; see Eq. 1) inferred from the studies as a component of field-scale water management.

\section{Methods}

\subsection{Literature search query}

We scanned the Web of Science and the SCOPUS database on 5 February 2020 with a query covering all global BECCS and bioenergy studies that mention use, consumption, withdrawal, or demand of water in their abstract, keywords, or title and excluded studies which focused on algae or electrofuels:

("BECCS" OR "bioenergy production" OR
"bioenergy cultivation" OR "biomass
production" OR "biomass plantation*")
AND (( "water" AND ("use" OR "demand"
OR "consumption" OR "withdrawal"))
OR "irrigation") AND ("global") NOT
("algae" OR "algal" OR "electrofuels").

From the resulting 430 studies, we removed those that do not deal with BPs or BECCS at all, have only a regional scope, or only give qualitative estimates of the freshwater abstractions of large-scale BPs (going from title to abstract to full text). The global bioenergy studies with water consumption values by King et al. (2013); Smith et al. (2016); Smith and Torn (2013); Varis (2007); Séférian et al. (2018) were included as supplementary "green water studies" in our corpus because they did not consider irrigation, rather only rainfed biomass plantations (and CCS process water in the case of Séférian et al., 2018). We manually added the study by Hejazi et al. (2014), which did not show up in the systematic query described above. The resulting total of 16 "blue water" publications ( +5 "green water") together with the main parameters are listed in Table 1. Noticeably, the majority of publications are very recent - only two of them were published before 2010 .

\subsection{Calculating an inverse water-use efficiency (iwue)}

Comparison of the literature values of water abstractions for BECCS is not straightforward because of the different assumptions studies made on important model parameters and setups, as described in Sect. 3.2. Nevertheless, besides presenting the absolute global estimates of freshwater withdrawal or consumption, we attempt to make the results of these studies directly comparable. The degree of assumed bioenergy deployment varies strongly among studies. We thus relate the given freshwater abstractions to the absolute amount of biomass assumed to be grown. With this we quantify the estimated water abstractions per harvested biomass. King et al. (2013) compute a similar "bioenergy water-use efficiency at the farm gate" for several lignocellulosic bioenergy species based on the yield of (bio)energy per hectare per water volume evapotranspired. We extend this concept of local level water-use efficiency to the larger spatio-temporal scale and apply it as an inverse (global) water-use efficiency (iwue):

iwue $\left[\frac{\mathrm{km}^{3}}{\mathrm{GtC}}\right]=\frac{\text { water }\left[\mathrm{km}^{3}\right]}{\text { biomass harvest }[\mathrm{GtC}]}$.

For the analysis, we separate the scenarios into those that report water withdrawals or consumption per energy unit supplied from bioenergy ("energy studies") and those that report NEs along with estimates of related withdrawals or consumption ("NE studies"). From the energy studies, we backtrack the approximate dry biomass harvests by using the gross calorific value of $18.5 \mathrm{MJ} \mathrm{kgDM}^{-1}$ (Haberl et al., 2010; Brosse et al., 2012). This is equivalent to $37 \mathrm{MJ} \mathrm{kgC}^{-1}$ or $37 \mathrm{EJ} \mathrm{GtC}^{-1}$, with the average carbon content of dry biomass being $0.5 \mathrm{kgC} \mathrm{kgDM}^{-1}$ (Schlesinger and Bernhardt, 1991, p. 120) (Eq. 2).

biomass harvest from energy $[\mathrm{GtC}]=\frac{\text { energy }[\mathrm{EJ}]}{37 \mathrm{EJ} \mathrm{GtC}^{-1}}$

With this we approximate the initial biomass harvest from the reported bioenergy supply, however, neglecting losses during processing if they were considered. Note that using one value for carbon content of biomass is an oversimplification; naturally, the value depends on the bioenergy crop type (Ma et al., 2018). Therefore, for ideal comparability not only the feedstock type but also the harvest shares would need to be reported. For NE studies that document an assumed carbon conversion efficiency $\left(c_{\text {eff }}\right.$; the fraction of carbon from biomass harvest that is eventually sequestered and removed from carbon cycling), we derive the dry biomass harvest by division of the NE amount by $c_{\text {eff }}$ (Eq. 3). Since transport and other losses are usually contained in $c_{\text {eff }}$, the inferred initial biomass values for NE studies are probably more reliable than those for energy studies.

biomass harvest $f_{\text {from } \mathrm{NE}}[\mathrm{GtC}]=\frac{\mathrm{NE}[\mathrm{GtC}]}{c_{\mathrm{eff}}}$ 
Table 1. List of publications with published key bioenergy parameters analysed in this review. See supplementary dataset (Stenzel et al., 2021) for additional parameters and all scenarios per study.

\begin{tabular}{|c|c|c|c|c|c|c|c|c|}
\hline Author & $\begin{array}{l}\text { Year } \\
\text { (public.) }\end{array}$ & $\begin{array}{r}\text { Area } \\
{[\text { Mha] }}\end{array}$ & $\begin{array}{r}\text { Energy } \\
{\left[\mathrm{EJ} \mathrm{yr}^{-1}\right]}\end{array}$ & $\begin{array}{r}\mathrm{NE} \\
{\left[\mathrm{GtC} \mathrm{yr}^{-1}\right]}\end{array}$ & $\begin{array}{l}\text { Year } \\
\text { (scen.) }\end{array}$ & $\begin{array}{r}\text { Water abstraction } \\
{\left[\mathrm{km}^{3} \mathrm{yr}^{-1}\right]}\end{array}$ & $\begin{array}{l}\text { Water } \\
\text { process }^{b}\end{array}$ & $\begin{array}{r}\text { c_eff }^{c} \\
{[\%]}\end{array}$ \\
\hline \multicolumn{9}{|l|}{ Blue water studies } \\
\hline Beringer et al. (2011) & 2011 & $142-454$ & $52-174$ & - & 2050 & $1481-3880$ & cons & - \\
\hline Berndes & 2002 & - & 304 & - & 2100 & 2281 & cons & - \\
\hline Bonsch et al. (2016) ${ }^{\mathrm{a}}$ & 2016 & $468-740$ & 300 & - & 2100 & $3362-5860$ & wd & $31-43$ \\
\hline Boysen et al. (2017) ${ }^{a}$ & 2017 & 441 & - & - & 2100 & $125-2536$ & cons & 50 \\
\hline Fajardy et al. (2018) & 2018 & 930 & - & 3.3 & 2016 & 5700 & cons & 33 \\
\hline De Fraiture et al. (2008) & 2008 & 42.2 & - & - & 2030 & 128.4 & wd & - \\
\hline Gerbens-Leenes et al. (2012) & 2012 & - & 71 & - & 2030 & 466 & cons & - \\
\hline Heck et al. (2016) ${ }^{\mathrm{a}}$ & 2016 & 1500 & - & - & 2005 & $1344-1501$ & cons & - \\
\hline Heck et al. $(2018)^{a}$ & 2018 & $778-870$ & $151-233$ & $1.2-5.4$ & 2050 & 1525 & cons & $48-90$ \\
\hline Hejazi et al. (2014) ${ }^{a}$ & 2014 & $596-8195$ & $40-140$ & $0-10$ & 2095 & $1000-9000$ & wd & 94 \\
\hline Hu et al. (2020) ${ }^{a}$ & 2020 & 431 & - & 3.1 & 2100 & $2260-11350$ & cons & $36-72$ \\
\hline Humpenöder et al. (2018) & 2018 & 636 & 300 & - & 2100 & $973-1211$ & cons & - \\
\hline Jans et al. (2018) ${ }^{a}$ & 2018 & $400-4300$ & $200-2350$ & - & 2015 & $1300-9000$ & cons & - \\
\hline Mouratiadou et al. (2016) & 2016 & 511 & 400 & - & 2100 & 2700 & wd & - \\
\hline Stenzel et al. (2019) ${ }^{\mathrm{a}}$ & 2019 & $1072-1416$ & - & $4.4-8.9$ & 2100 & $351-2946$ & cons & $50-70$ \\
\hline Yamagata et al. (2018) & 2018 & 250 & - & 2.9 & 2095 & 1910 & cons & 33 \\
\hline \multicolumn{9}{|l|}{ Green water studies } \\
\hline King et al. (2013) & 2013 & $363-493$ & $33-47$ & - & 2050 & 1000 & cons & - \\
\hline Séférian et al. (2018) & 2018 & - & $220-270$ & - & 2100 & 178 & cons & - \\
\hline Smith and Torn (2013) & 2013 & 218-990 & - & 1.0 & 2100 & $1600-7400$ & cons & 47 \\
\hline Smith et al. (2016) & 2016 & 100-200 & - & 3.3 & 2100 & 720 & cons & 100 \\
\hline Varis $(2007)$ & 2007 & - & 83.52 & - & 2050 & 2088 & cons & - \\
\hline
\end{tabular}

${ }^{a}$ Parameter ranges span several scenarios. ${ }^{b}$ Consumption (cons), withdrawals (wd). ${ }^{\mathrm{c}}$ Carbon conversion efficiency.

Some studies also consider the residues from agriculture and forestry (Beringer et al., 2011; Fajardy et al., 2018), timber harvest from land-use conversion (Heck et al., 2018; Stenzel et al., 2019), municipal solid waste, or animal manures (Beringer et al., 2011) as bioenergy feedstock. Respective amounts, however, are only reported in Beringer et al. (2011)). We may therefore overestimate the raw bioenergy harvests or conversely underestimate the water abstractions per unit of biomass from dedicated BPs.

\section{Results and discussion}

\subsection{Overview}

We synthesize the results from the 16 publications into 34 scenarios of freshwater abstractions for bioenergy (the full dataset is available in Stenzel et al., 2021). As freshwater abstractions, we extract reported estimates of blue water consumption or withdrawals, with a preference on consumption.

The modelling approaches used are very different, with each model focusing on a different part of the BECCS deployment process. While Earth system models (ESMs) dynamically represent large-scale feedbacks between the at- mosphere, ocean, and biosphere, with comparably less process detail regarding human management of the biosphere including BPs, integrated assessment models (IAMs) focus on future developments of, e.g. land and water use based on biophysical and economic boundary conditions - explicitly accounting for decisions on BP locations and resource use. In contrast, climate or land-use patterns are typically prescribed to vegetation or hydrological models, which in turn usually operate at higher spatio-temporal resolution and provide more process-based interactions, especially regarding the simulation of water availability and withdrawal. If deriving global estimates of BP freshwater withdrawal or consumption is an aim of a study, more straightforward and computationally inexpensive estimations might suffice. Value chain models might be best suited if the details of the BECCS process chain are of most interest.

The natural water availability in bioenergy modelling studies is largely determined by the considered climate input, which in the case of projections for the future also varies among the general circulation models used. In this regard, local water abstraction projections might also be analysed in terms of the projected climate-driven water availability changes in the respective region. 
There could be potential bias of the dataset due to one model providing data for the majority (LPJmL; 9 out of 16 including studies based on the MAgPIE model that uses some input from LPJmL) of the studies; however, these studies also differ in terms of land type and area used for bioenergy cultivation, irrigation management, or structural parameters (carbon conversion efficiency or bioenergy demand trajectory) as can be seen in the spread in Figs. 2, A2, and the supplementary data (Stenzel et al., 2021).

All of the studies targeted in this review also consider rainfed plantations that depend solely on green water stored in the soil (with added irrigation if necessary); however, the amount of evapotranspired green water is only reported in a few of them. An overview of studies reporting global green water abstraction for bioenergy, which either do not consider irrigated BPs (Séférian et al., 2018; Smith and Torn, 2013; Smith et al., 2016) or do not specify where the source of the evapotranspired water (King et al., 2013; Varis, 2007) is given in Fig. A3. According to these studies, green water consumption of bioenergy ranges from 50 to over $3000 \mathrm{~km}^{3} \mathrm{GtC}^{-1}$ of biomass harvest. Since this review focuses on blue water requirements, those estimates are not included in the main analysis.

Focusing on the blue water abstractions allows us to directly compare them in the light of competition with other human water uses and those of aquatic ecosystems, potentially increasing overall water stress. A useful objective of future studies would be a more comprehensive quantification of the water requirements of bioenergy systems, partitioning sources into green and blue pathways and identifying potential means of increasing water-use efficiency and decreasing blue water abstractions. However, the current review is timely since information on the relative magnitudes of green and blue water demands of large-scale bioenergy implementation, relative to other social and environmental needs, is needed now for the best decision-making and policy development.

\subsection{Study differences in parameter choices and other assumptions}

Study type. According to our literature review, estimating future global water abstractions of BPs is being approached with a variety of models and methodologies. Berndes (2002) uses projections based on measured evapotranspiration fluxes from field studies (e.g. Berndes and Borjesson, 2001) combined with bioenergy demand scenarios (e.g. Nakićenović et al., 1998, p. 72-75) to compute the global freshwater consumption of BPs. Hu et al. (2020) use a similar approach by inversely calculating biomass harvest demands for RCP2.6 (Vuuren et al., 2011) for three scenarios of carbon conversion factors, combined with literature values of water-use efficiencies for two $\mathrm{C}_{4}$ grasses. Most studies rely on numerical simulation models based on an energy (or NE) trajectory controlling the location, productivity, and eventually water abstrac- tions for BPs (here referred to as "demand-driven studies") or have the aim to find the maximum energy (or NE) potential within given constraints of available land, water restrictions, or management ("supply-driven studies"). Examples of the former category of studies are De Fraiture et al. (2008), Mouratiadou et al. (2016), Humpenöder et al. (2018), and Stenzel et al. (2019) and of the latter category are Beringer et al. (2011), Jans et al. (2018), and Fajardy et al. (2018).

Modelling framework. While Berndes (2002) and $\mathrm{Hu}$ et al. (2020) derived their results mainly from meta-analyses of existing literature and approximations of global water consumption by extrapolating current water-use efficiencies for future energy demand scenarios, others are based on simulations from quite sophisticated global process models of different types. Bonsch et al. (2016), Mouratiadou et al. (2016), and Humpenöder et al. (2018) used the MAgPIE agroeconomic model determining the water withdrawal or consumption for BPs under different scenario constraints. Bonsch et al. (2016) specifically investigated the tradeoffs between area and water withdrawals by comparing rainfed and irrigated BPs, while Humpenöder et al. (2018) analysed environmental and socioeconomic indicators in bioenergy scenarios. The majority of studies considered here (Beringer et al., 2011; Heck et al., 2016; Boysen et al., 2017; Heck et al., 2018; Jans et al., 2018; Stenzel et al., 2019) were based on a single dynamic global vegetation model (DGVM), LPJmL, yet used different model setups and imposing varied constraints to water availability and use (biophysical potentials from LPJmL were also used as input to MAgPIE-based studies). The main study goals were global bioenergy potentials and the associated tradeoffs with global water consumption, plantation area demand, or planetary boundaries.

The water (and land) implications of increasing biofuel production in the future were analysed in De Fraiture et al. (2008) with the water-use model WaterSIM and in GerbensLeenes et al. (2012) with the agricultural decision support tool CROPWAT. Yamagata et al. (2018) assessed the impact of large-scale BECCS deployment on land use, water resources, and ecosystem services using the global hydrological model H08 together with the terrestrial ecosystem model VISIT. Fajardy et al. (2018) base their analysis of the whole BECCS supply chain on the MONET value chain model, while Hejazi et al. (2014) employ a combination of GCAM (an IAM) in conjunction with the global hydrological model GWAM to quantify global water scarcity under several future climate change scenarios.

Bioenergy plantation area. The global potential plantation area identified as suitable for BPs differs hugely in size between 42 Mha in De Fraiture et al. (2008) (only biofuels) and 8195 Mha in Hejazi et al. (2014), with the median area being 616 Mha (see Figs. 1 and A1). Reported maps show locations scattered around the globe (Stenzel et al., 2019), with clusters in central Europe, North and South America and north-east China in Beringer et al. (2011) or South America and central Africa in Bonsch et al. (2016). Note, however, that BP area 

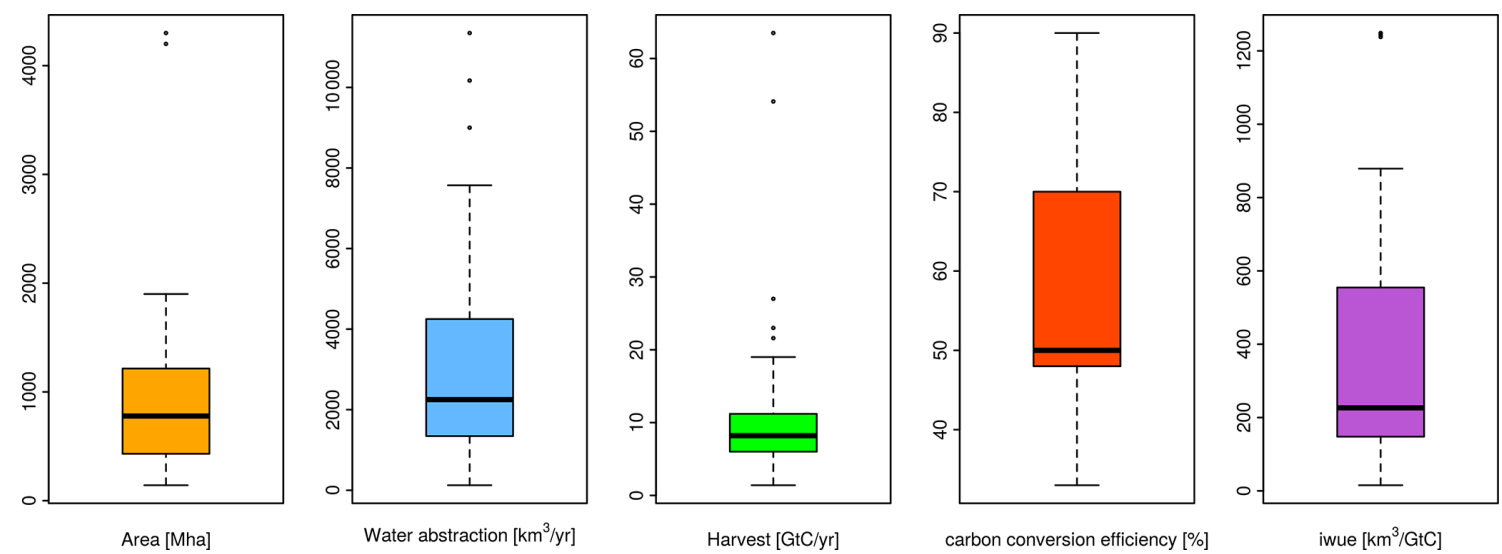

Figure 1. Range of key parameters (global estimates) determining projections of water abstractions for bioenergy in the scenarios examined (see supplementary data; Stenzel et al., 2021) presented as boxplots. Note that plantation area and carbon conversion efficiency are not reported in all studies. Inverse water-use efficiency per biomass harvest (iwue) is calculated for each scenario using the means of water abstractions and biomass harvest if ranges are given.

size and especially location-specific water-use maps are not reported in every study, but would be crucial to compare and interpret the projected magnitudes of global freshwater consumption as determined by the water availability and requirements in the respective locations (King et al., 2013). Studies without explicit bioenergy locations thus need to be interpreted with caution.

The (geospatial) location of additional large-scale irrigation might also be relevant from the perspective of feedbacks with the climate system (Moore and Rojstaczer, 2002). Recently it was suggested that the influence of land-cover change and especially irrigation on evapotranspiration are larger than expected (Van Noordwijk and Ellison, 2019; Ellison et al., 2019), such that moisture recycling through transpired irrigation water and moisture transport to downwind regions may also be affected by the biomass plantations. Thus, for example, as long as forests are not removed in order to grow the biomass material, the upwind production of additional biomass material could potentially have positive impacts on downwind rainfall and water availability (DeAngelis et al., 2010; Layton and Ellison, 2016). These atmospheric linkages make it all the more important to consider such interventions both strategically and spatially with the potential to find synergies in cases where upwind irrigation under high water availability might provide additional precipitation to dry downwind regions. New modelling approaches tracking atmospheric moisture pathways (Tuinenburg and Staal, 2020) or direct coupling of land-system and climate models (Pokhrel et al., 2017) help us to better understand these processes.

The reported land types, which are projected to be converted to BPs, show a large variety covering marginal land (e.g. Smith et al., 2016), and natural vegetation, partially excluding protected or vulnerable lands (e.g. Beringer et al., 2011). Some studies create new overall land-use patterns based on spatial and temporal optimization of costs (e.g. Humpenöder et al., 2018) or environmental impacts (e.g. Heck et al., 2018); others use existing exogenous projections for designated BP areas (e.g. from RCP2.6-based studies in Boysen et al., 2017). Conversion of cropland to bioenergy plantations is generally avoided (except in Yamagata et al., 2018 and Heck et al., 2016). Current cropland extent amounts to 1564 Mha (Klein Goldewijk et al., 2017). The potentially (theoretically) available land for biomass plantations today in each of the remaining categories would be: $385-472$ Mha for marginal land (Campbell et al., 2008), 6899 Mha for natural vegetation (Boysen et al., 2017), 3286 Mha for natural vegetation excluding protected or vulnerable land (Stenzel et al., 2019), and 441 Mha for the BP area in RCP2.6-SSP2 in 2100 (Boysen et al., 2017).

Irrigation parameters. Within the studies that explicitly model irrigation of BPs, there is also strong variation in the parameterization of the irrigation systems. Some studies allow potential irrigation, i.e. assuming unlimited availability of surface or groundwater and neglecting feedbacks resulting from water demands higher than available resources (Hejazi et al., 2014). Conversely, irrigation is in some studies simulated to be constrained by surface water availability (Beringer et al., 2011; Heck et al., 2016) or even further constrained by additionally accounting for so-called "environmental flow requirements" (EFRs) to be withheld for protection of riverine ecosystems (Jans et al., 2018; Humpenöder et al., 2018; Stenzel et al., 2019). Additionally, the water losses due to different efficiencies of irrigation systems can in theory vary between $<30 \%$ for surface irrigation and $>70 \%$ for drip irrigation (productive share of the withdrawals in Jägermeyr et al., 2015). Irrigation efficiencies for BPs are typically assumed to be rather on the upper end of this range (e.g. $66 \%$ in Humpenöder et al., 2018). Also, the fraction of plantations that are allowed to be irrigated varies widely. In their 
"IrrExp" scenarios, Stenzel et al. (2019), e.g. allow for irrigation on all plantations, which would benefit from this irrigation constrained only by the availability of surface water and EFRs, while their "TechUp" and "Basic" scenarios are limited to $30 \%$ of irrigated areas - those with high water productivities preferred.

Biomass feedstock. The majority of scenarios consider $\mathrm{C}_{4}$ grasses like Miscanthus or switchgrass (29/34), temperate $(18 / 34)$, and tropical tree species (17/34) as bioenergy feedstock (e.g. Boysen et al., 2017; Yamagata et al., 2018; Heck et al., 2018). Among the reviewed studies, only two consider first-generation bioenergy plants like rapeseed, oil palm, or sugar cane as feedstock (De Fraiture et al., 2008; GerbensLeenes et al., 2012). Residues from agriculture or forestry, estimated to contribute up to $100 \mathrm{EJ} \mathrm{yr}^{-1}$ in 2050 (IEA, 2009; Haberl et al., 2010), are discussed by Beringer et al. (2011) but not included in their analysis. Stenzel et al. (2019) and Heck et al. (2018) include the one-time timber harvest from the land-use conversion of forests to biomass plantations. Fajardy et al. (2018) include wheat straw residues as biomass feedstock. However, in the context of the current review, major impacts on water can probably only be expected by designated large-scale plantations.

Some studies assume yield productivity changes in the bioenergy harvest over the 21st century based on previous productivity increases observed in crop harvests (Bonsch et al., 2016; Mouratiadou et al., 2016; Humpenöder et al., 2018). There is also the argument that this increase of productivity might be more difficult to reach than for food crops, since the whole above-ground biomass is used for bioenergy production instead of only a small ratio as in the case of food crops (Krausmann et al., 2013). Breeding programmes might also yield significant potential for improved water-use efficiencies in bioenergy crops.

Timing of bioenergy implementation. For demand-driven studies, crucial (but mostly exogenous) parameters are the starting year and trajectory for the BECCS demand, e.g. whether deployment is assumed to start in 2015 (Humpenöder et al., 2018) or in 2030 (Stenzel et al., 2019). Trajectories of the energy (or NE) demand (Boysen et al., 2017; Hejazi et al., 2014; Berndes, 2002) that require higher yearly biomass yield demands at the end of the century will likely also lead to higher yearly irrigation requirements. The yearly water abstractions given in the studies are not always indicative of average irrigation water abstractions per year, since demand studies mostly report end-of-study-period values (e.g. mean 2090-2099) when irrigated areas are at their maximum.

Carbon conversion efficiency. An important parameter in the BECCS process chain (and indirectly influencing the water demand of BPs) is the carbon conversion efficiency $\left(c_{\text {eff }}\right)$, which we define as the overall fraction of harvested biomass carbon that can be sequestered and thus removed from carbon cycling. Gough and Vaughan (2015) report the capture rates of the CCS processes to be $85 \%$ to $90 \%$, but these ranges only describe the CCS efficiency and disregard the supply chain carbon efficiency, which can be much lower. Smith and Torn (2013) give an overall conversion efficiency of $47 \%$ for typical BECCS process chains. For our literature corpus, $c_{\mathrm{eff}}$ (if reported at all) ranges from $31 \%-33 \%$ (Bonsch et al., 2016; Fajardy et al., 2018; Yamagata et al., 2018) to $94 \%$ (Hejazi et al., 2014) (Fig. 1).

Other constraints. As already briefly discussed in the context of irrigation parameters, the studies from our literature corpus consider some other constraints to large-scale BECCS implementation that are also likely to influence their freshwater abstractions. Limiting human intervention with the environment, specifically by respecting planetary boundaries (Rockström et al., 2009; Steffen et al., 2015), might limit the BECCS potential significantly as shown in Heck et al. (2018). Similarly, Bonsch et al. (2016) identify a tradeoff between irrigation water and plantation area demand, which corresponds to tradeoffs with planetary boundaries for freshwater use, biosphere integrity, and land-system change. Additionally, economic constraints such as the accessibility of BPs, their distance to cities where most energy is needed, and the availability of large geologic storage capacity close to the locations of energy consumption are to be mentioned as further determinants of bioenergy water abstractions (e.g. considered in Fajardy et al., 2018).

\subsection{Projections of global irrigation water abstractions for bioenergy plantations}

From the 16 studies, we synthesized 34 scenarios, for which we collected the projected freshwater abstractions and associated data (see supplementary data; Stenzel et al., 2021). We collected the type of study, the modelling framework, the bioenergy feedstock, the land type converted to a biocrop plantation, whether global maps for bioenergy locations are included, whether withdrawal or consumption is reported, the type of water (blue/green/grey), the simulation year for which data is extracted, $c_{\text {eff }}$, the plantation area, the provided bioenergy, and/or the NEs (depending on study type).

The projections of potential future freshwater consumption for irrigation of BPs $\left(125-11350 \mathrm{~km}^{3} \mathrm{yr}^{-1}\right)$ vary substantially due to differences in model structure, scenarios, study goals, and data input. Extreme cases are the FFICTB2 scenario in Hejazi et al. (2014) and the Food First (FF) scenario in Jans et al. (2018), who simulate BP cultivation on 4000-8000 Mha with associated water withdrawals of $5500-9000 \mathrm{~km}^{3} \mathrm{yr}^{-1}$. These scenarios include extremely high amounts of irrigated BPs (Hejazi et al., 2014) or are maximum potential scenarios (largely unconstrained in terms of available area) (Jans et al., 2018) and, at least in the latter case, are not meant to be implemented as such. Assuming water-use efficiencies of $585 \mathrm{~m}^{3} \mathrm{t}^{-1}$ for Miscanthus, Hu et al. (2020) project the water consumption on RCP2.6 consistent $\mathrm{BP}$ areas (431 Mha) to be up to $11350 \mathrm{~km}^{3} \mathrm{yr}^{-1}$. 

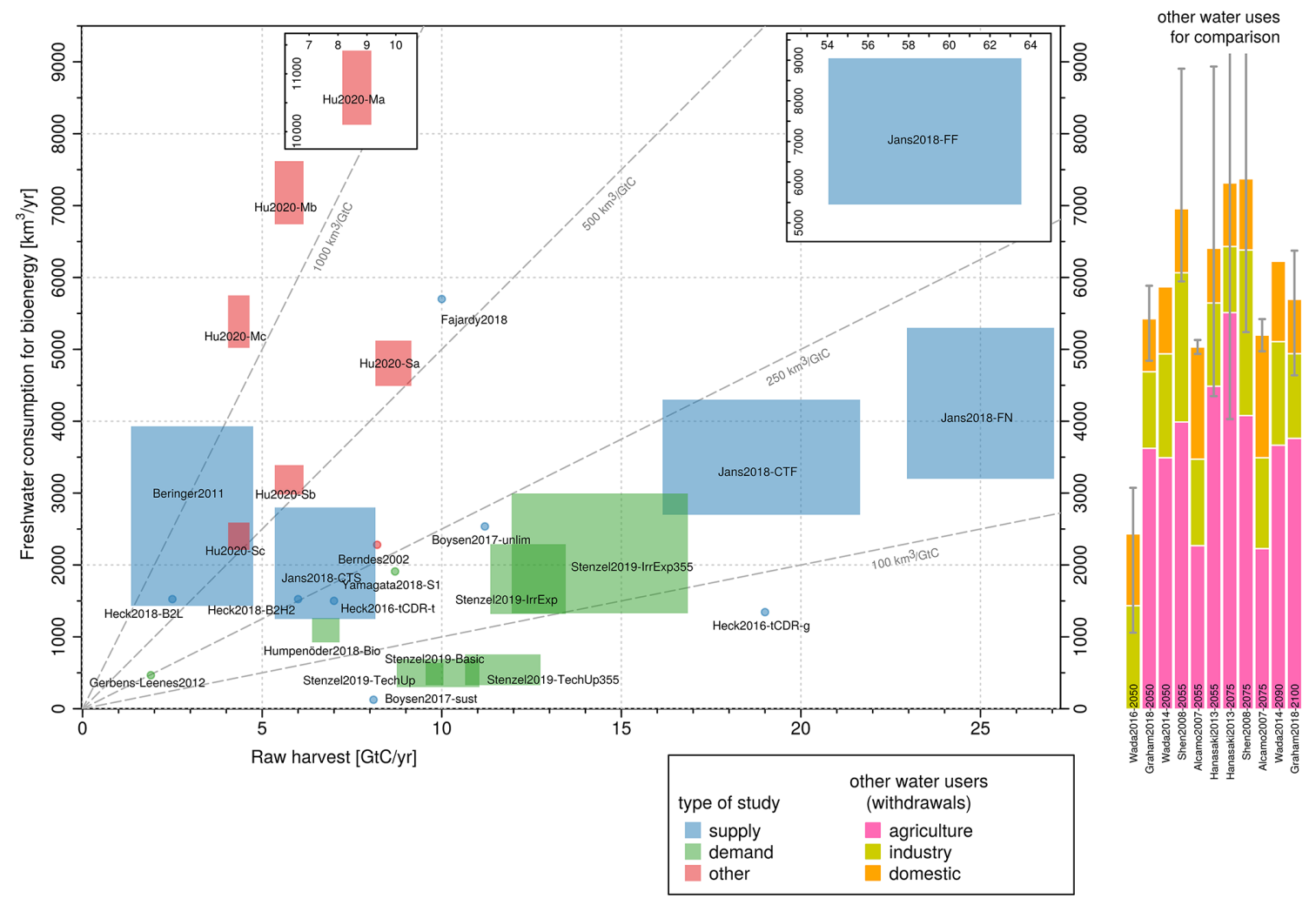

Figure 2. Overview of scenarios of reported values of global blue water consumption required for bioenergy production through biomass plantations (inlays show scenarios outside the plotting region). Scenarios are characterized by freshwater consumption for bioenergy plotted against raw harvest (inferred from reported biomass based energy or negative emissions). They can provide ranges in water withdrawals or raw harvest (illustrated by boxes) or contain single values (depicted by circles). The type of study is marked by the colour. Results for studies that report blue water withdrawals can be found in Fig. A2 and studies of green water consumption in Fig. A3. For contextualization, projections for other water uses (withdrawals) are shown to the right together with their uncertainty ranges. Names of the bioenergy scenarios are constructed as $\{$ author $\}$ \{publication year\}-\{scenario name $\}$ and those of "other water use" scenarios as $\{$ author $\}$ publication year\}\{simulation year $\}$.

\subsection{Bioenergy plantation water abstractions in light of water use in other sectors}

The contemporary global green and blue water consumption on cropland is $5000-10000$ and $800-1500 \mathrm{~km}^{3} \mathrm{yr}^{-1}$, respectively (Hoff et al., 2010; Jägermeyr et al., 2015; Rosa et al., 2018). Runoff feeding these appropriations globally sums up to approximately $40000 \mathrm{~km}^{3} \mathrm{yr}^{-1}$ (Sperna Weiland et al., 2010; Gerten et al., 2013), of which, however, only $30 \%-$ $40 \%$ is geographically and temporally accessible to humans (Postel et al., 1996).

To contextualize the above-discussed estimations of irrigation water abstractions for bioenergy, earlier projections of future water use for the three main other sectors of agriculture, industry, and households are collected (Alcamo et al., 2007; Shen et al., 2008; Hanasaki et al., 2013b, a; Wada and Bierkens, 2014; Wada et al., 2016; Graham et al., 2018) and compiled for comparison (see Fig. 2 and supplementary data). Agriculture is globally the largest water-using sector among the three, with a global total irrigated area re- ported to be 306 Mha in 2000 (Siebert et al., 2015). Estimates of present (between 2000 and 2010) agricultural water withdrawal are in the range of $2402-3214 \mathrm{~km}^{3} \mathrm{yr}^{-1}$. Future agricultural water withdrawal is projected by grid-based numerical hydrological or crop growth models. For the mid(around 2050) and the late 21st century (between 2075 and 2090), estimates range between $2256-6037 \mathrm{~km}^{3} \mathrm{yr}^{-1}$ and $2211-8434 \mathrm{~km}^{3} \mathrm{yr}^{-1}$, respectively. These wide ranges in estimations are primarily attributed to the assumptions on future irrigated area, which differ widely, as in the case of BP projections. The lower ends assume that the irrigated area hardly increases in the future, based on the view that land for new irrigation projects is no longer available (e.g. Alcamo et al., 2007 and the low-end scenario of Hanasaki et al., 2013a). The high-end projection assumes that the irrigated area increases at a rate of $0.6 \% \mathrm{yr}^{-1}$ (i.e. the high-end scenario of Hanasaki et al., 2013a). Another case assumes that agricultural water use grows in proportion to the total population as observed in the latter half of the 20th century (Shen et al., 2008). Other assumptions with respect to changes in irri- 
gation efficiency, crop intensity, and climate change further widen the range of estimates.

Industry and domestic water use are the second- and thirdlargest water-using sectors. The estimates of present industrial and domestic water withdrawals are in the range of 691894 and $328-474 \mathrm{~km}^{3} \mathrm{yr}^{-1}$, respectively. Future industrial and domestic water withdrawal is projected using empirical approaches. For instance, Alcamo et al. (2003) and Alcamo et al. (2007) developed nationwide regression models to model water withdrawal in response to key drivers (e.g. population, income, electricity production, efficiency improvements) used in an exponential form to express the empirical facts that per activity water use continuously drops through time. Future industrial water withdrawals in the middle and the late 21 st century are estimated to range between 433 3313 and between $246-3772 \mathrm{~km}^{3} \mathrm{yr}^{-1}$, respectively. These ranges primarily reflect differences in efficiency improvement settings. As for domestic water, ranges are 628-1563 and $573-1726 \mathrm{~km}^{3} \mathrm{yr}^{-1}$, respectively, for the two future time periods.

The median (first and third quartile) of total water withdrawal for the present and the mid- and late 21 st century is 3770 (3724-3824), 5806 (5311-6378), and 6076 (5063$6984) \mathrm{km}^{3} \mathrm{yr}^{-1}$, respectively.

Figures 2 and A2 indicate that 19 out of 34 estimations for global additional irrigation water withdrawal for bioenergy exceed $2000 \mathrm{~km}^{3} \mathrm{yr}^{-1}$, which corresponds to half of the present water withdrawals. This additional volume is roughly equivalent to the differences in total water withdrawal between SSP1 $\left(4295 \mathrm{~km}^{3} \mathrm{yr}^{-1}\right.$; SSP $=$ shared socioeconomic pathway), SSP2 (6369 $\left.\mathrm{km}^{3} \mathrm{yr}^{-1}\right)$, and SSP3 $\left(8827 \mathrm{~km}^{3} \mathrm{yr}^{-1}\right)$ in 2050 (Hanasaki et al., 2013a). A significant increase in water withdrawal for biomass production is likely to intensify water stress in the respective regions if not carefully planned in view of other water uses. The estimated global total water stressed population for SSP1, SSP2, and SSP3 are 2853, 3642 , and 4265 million people. Although the water usage is different, it implies that $2000 \mathrm{~km}^{3} \mathrm{yr}^{-1}$ of additional irrigation may increase the water-stressed population by $600-800$ million people (Hanasaki et al., 2013a). Importantly, integrative studies that account for all major water users including bioenergy in a consistent framework at global scale yet spatially explicit are basically lacking.

The future price of biomass, as well as the value of freshwater, also likely depends on political decisions (Klein et al., 2014) or market forces in other sectors (Dinar and Mody, 2004). Integrated assessments of the combined effects in a globally monetized biomass and food market with potential limitations of irrigation water withdrawals (Hogeboom et al., 2020) or associated high costs (De Fraiture and Perry, 2002), especially under conditions of continued climatic change, poses interesting avenues for further research.

\subsection{Inverse water-use efficiency relating freshwater abstractions and harvest}

Reported primary bioenergy (energy content of the biomass harvest to be converted to electricity) ranges from 40 to $2350 \mathrm{EJyr}^{-1}$, while NEs range from 1.2 to $10.0 \mathrm{GtC} \mathrm{yr}^{-1}$. After converting primary bioenergy and NEs to initial biomass harvests (see Sect. 2.2), we find the projections of global freshwater abstractions per harvested biomass (iwue) to be in the range of 15 to $2761 \mathrm{~km}^{3} \mathrm{GtC}^{-1}$ (15$1,250 \mathrm{~km}^{3} \mathrm{GtC}^{-1}$ if the mean scenario values are used; Fig. 1). This large range shows that freshwater withdrawals or consumptions do not linearly depend on the amount of cultivated biomass; it is rather the large variety in other parameters (which cannot be made comparable) that primarily discriminates the scenarios (Figs. 2 and A2). Scenarios "sust" from Boysen et al. (2017), "Basic", "TechUp", and "TechUp355" from Stenzel et al. (2019), and "tCDRg" from Heck et al. (2016) demonstrate iwue values below $100 \mathrm{~km}^{3} \mathrm{GtC}^{-1}\left(15,50,49,46\right.$ and $\left.71 \mathrm{~km}^{3} \mathrm{GtC}^{-1}\right)$.

In the theoretical scenario tCDR-g in Heck et al. (2016), no additional BP locations are determined, but all existing croplands in year 2005 are assumed to be replaced with BPs and assumed to be irrigated very efficiently, which results in high harvests and thus low iwue. In the "sust scenario" considered in Boysen et al. (2017), only 40 out of a total 441 Mha BP area are considered to be irrigated, but the authors do not provide values to discriminate the respective harvests. In their "TechUp-WM" scenario, Stenzel et al. (2019) assume a high $c_{\text {eff }}$ of $70 \%$ together with EFR restrictions on freshwater withdrawals, which keeps iwue below $100 \mathrm{~km}^{3} \mathrm{GtC}^{-1}$. The highest projected iwue values are from the $M^{*}$ scenarios from $\mathrm{Hu}$ et al. (2020) $\left(1102-1402 \mathrm{~km}^{3} \mathrm{GtC}^{-1}\right.$ ), Beringer et al. (2011) $\left(315-2761 \mathrm{~km}^{3} \mathrm{GtC}^{-1}\right)$, the "Baseline" $\left(909 \mathrm{~km}^{3} \mathrm{GtC}^{-1}\right)$ and "FFICT-B2" (849 km3 GtC-1) scenario from Hejazi et al. (2014), and the "Low-Yields" scenario from Bonsch et al. (2016) $\left(723 \mathrm{~km}^{3} \mathrm{GtC}^{-1}\right)$. Here we denote that the very high value $\left(2771 \mathrm{~km}^{3} \mathrm{GtC}^{-1}\right)$ from Beringer et al. (2011) might be an artefact of how we handle data value ranges, since the scenario producing the lowestenergy yields is most likely not the one with the highest water consumption; the scenario is probably rather following a trend of $1000 \mathrm{~km}^{3} \mathrm{GtC}^{-1}$.

However, we are still surprised to find that supply-driven studies do not consistently suggest higher harvest than demand-driven studies. This could mean that even demanddriven studies are operating at the limits of the Earth system, and supply-driven studies, especially when considering sustainability constraints, cannot provide more negative emissions than are already demanded for ambitious climate targets like $1.5^{\circ} \mathrm{C}$.

Only a few global studies consider biofuels (e.g. GerbensLeenes et al., 2012; De Fraiture et al., 2008), which (aside from the irrigation water abstractions for the bioenergy feedstock considered in this review) require additional water for 
processing. It should be noted that the additional water abstractions for the biofuel refinement process (on top of the in-field water abstractions) are considered in many regional life cycle assessment studies and assumed to be about 4 units of water per unit of ethanol according to Fike et al. (2007) and Keeney and Muller (2006). General assessments including both primary bioenergy and biofuels would need to consider different conversion efficiencies for the different biomass pathways (as in Bonsch et al., 2016 or Heck et al., 2018).

\section{Conclusions}

We report a large range of parameters and scenario criteria (Table 1 and more details in the supplementary data) that are crucial for estimating the irrigation water abstractions for BPs. We are not able to quantify the contribution of each parameter; however, strong dependencies are expected for the targeted primary bioenergy or negative emissions amounts, the assumed carbon conversion efficiency, and the assumed plantation area.

A number of necessary parameters were, however, not documented in the publications needed for a full assessment of the hydrologic implications of widespread BP deployment. Thus we recommend that all scenario parameters be reported in future publications on water use (including irrigation) of BPs, enabling more straightforward interpretation and comparison of results. A minimum set of reported parameters, ideally spatially detailed, should in our view include the complete water balances of BPs (including partitioning of blue and green water), water-use efficiencies of the respective plant types, rainfed and irrigated BP locations (including total area and climatic conditions), and total biomass harvest amounts.

We find the global water withdrawals for irrigation of biomass plantations estimated from the available literature to be in the range of 128.4-9000 $\mathrm{km}^{3} \mathrm{yr}^{-1}$ (consumption: 125$11350 \mathrm{~km}^{3} \mathrm{yr}^{-1}$ ), compared to about $1100-11600 \mathrm{~km}^{3} \mathrm{yr}^{-1}$ for the sum of other (agricultural, industrial, and domestic) water withdrawals and thus at similar magnitude. It needs to be noted that the water abstractions for bioenergy production would come on top of (or compete with) that for the other uses.

Surprisingly, there is no clear relationship (e.g. linear) between water abstractions and total bioenergy production. However, by comparing the freshwater abstractions per harvested biomass, we find that most of the scenarios fall between $100-1000 \mathrm{~km}^{3} \mathrm{GtC}^{-1}$. The full range of $15-$ $1250 \mathrm{~km}^{3} \mathrm{GtC}^{-1}$ for biomass harvest implies that, given a carbon conversion efficiency of $50 \%$, we might need 99$8250 \mathrm{~km}^{3}$ to reach NEs of $3.3 \mathrm{GtC} \mathrm{yr}^{-1}$ as projected to be necessary by Smith et al. (2016).
The studies analysed in this paper span a publication time of almost 20 years. There might, therefore, be significant changes even among different versions of the same model (e.g. GCAM in Hejazi et al., 2014 vs. in Graham et al., 2018, as discussed in Calvin et al., 2019), suggesting the need for a concerted model intercomparison for projections of bioenergy water demands under controlled assumptions and with the latest model versions.

These additional water abstractions for bioenergy, which are at the same magnitude of water demand projections for conventional usage seem to paint a picture of a future where water scarcity can become a global and perpetual issue.

It would have been desirable to also include regional studies in our analysis, but this would have required more information than is usually provided to, for example, analyse local yield and/or water productivity and data on other water-use sectors.

Besides the freshwater abstractions, potential impacts of BPs mostly stem from the implied land-cover and landuse conversion. Replacing natural vegetation with bioenergy crops could affect biodiversity, while, if grown on cropland, they could affect food security. Overall, most of the analysed scenarios do not explicitly replace existing cropland by BPs. This in turn means that most studies (at least implicitly) assume investments in additional infrastructure for irrigation assuming it is economically justifiable. Some scenarios also explicitly protect vulnerable natural areas. These considerations promote the use of marginal or degraded lands for BPs.

This review provides a first comprehensive overview of the current literature on global projections of the freshwater abstractions for irrigated bioenergy plantations. Furthermore, it is the first study that highlights the potential dependence on irrigation for BECCS to deliver NEs for ambitious climate targets and calls for further investigation and reporting on the underlying (model) assumptions. Integrated assessments that consider all water-use sectors (including bioenergy, along with potential tradeoffs based on a detailed understanding of local limitations) are highly desirable and are crucial to get a better understanding of the limits and options of future water consumption. 


\section{Appendix A: Supplementary information}

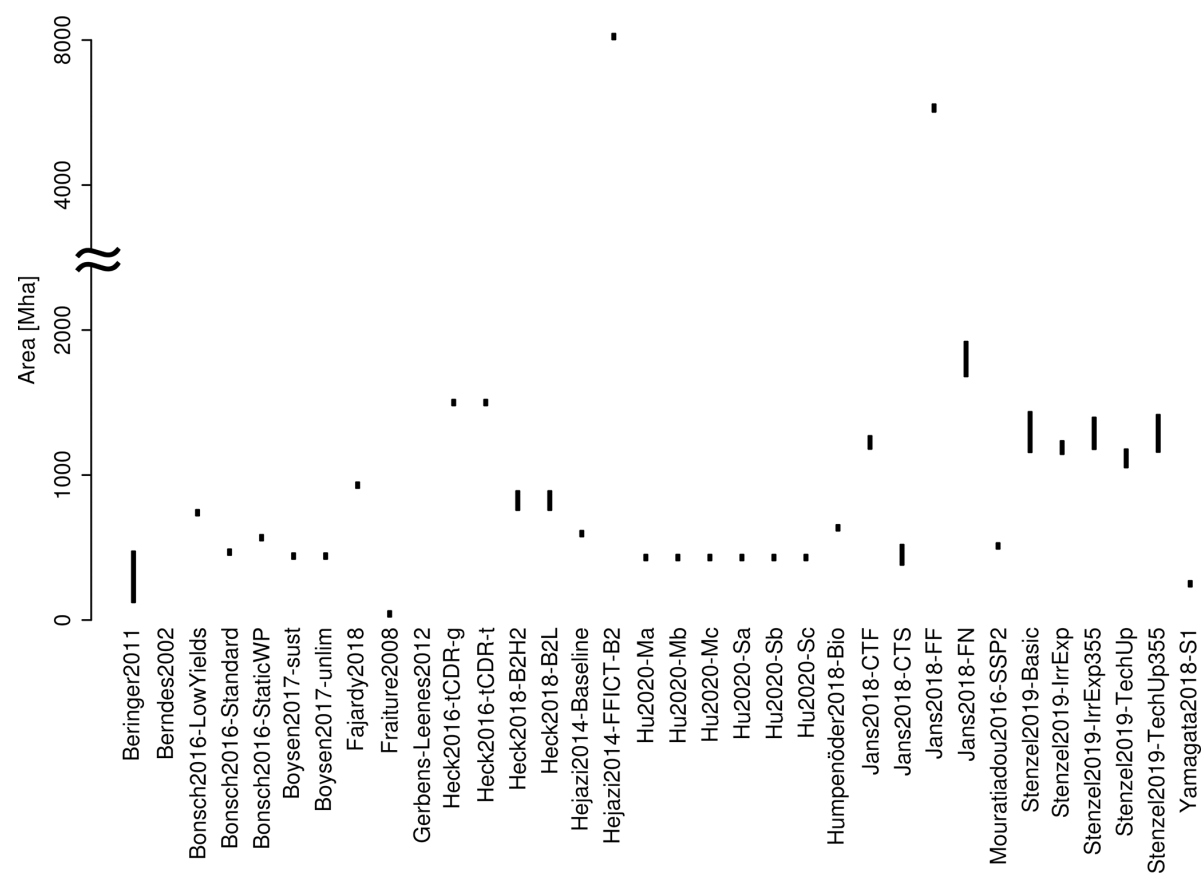

Figure A1. Overview of reported total global area of bioenergy plantations.

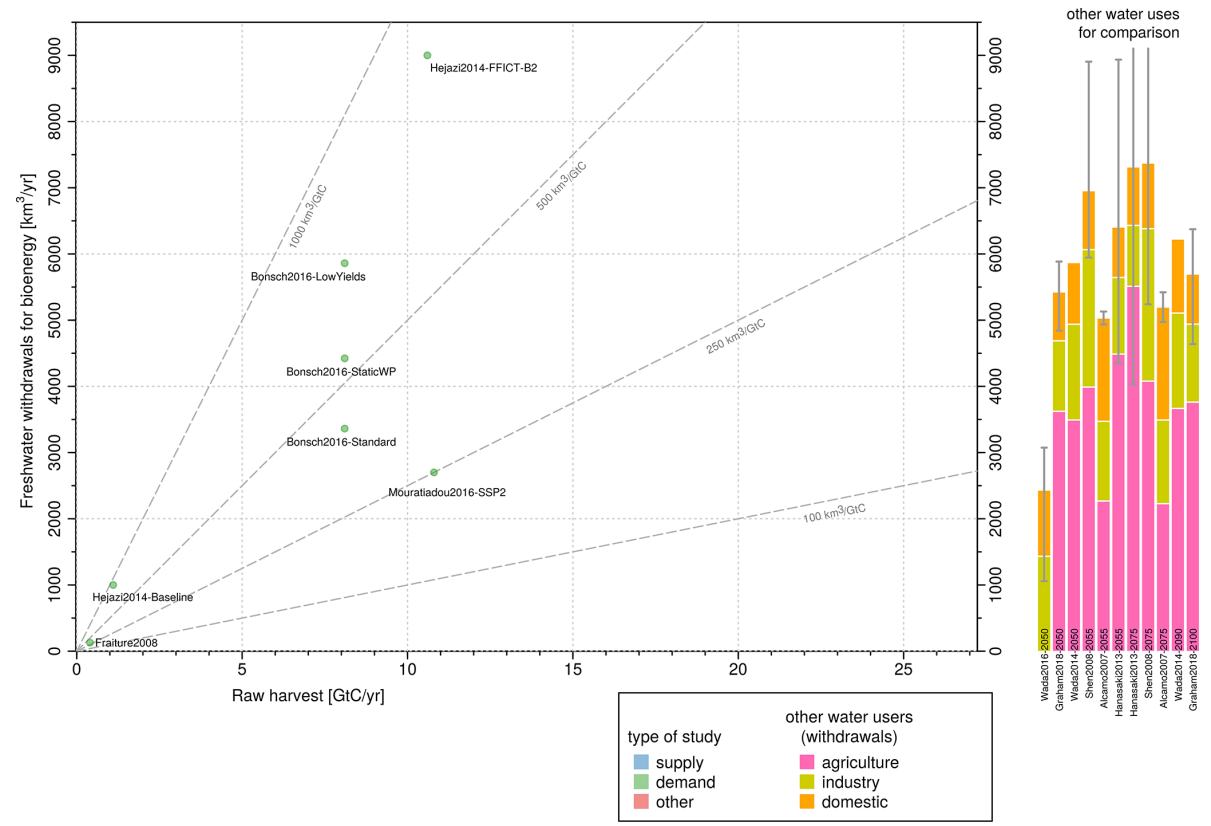

Figure A2. Analogous to Fig. 2 but for scenarios of reported values of global blue water withdrawals required for bioenergy production through biomass plantations. Scenarios are characterized by water withdrawals for bioenergy plotted against raw harvest (inferred from reported biomass based energy or negative emissions). They can provide ranges in water withdrawals or raw harvest (illustrated by boxes) or contain single values (depicted by circles). The type of study is marked by the colour. For contextualization, projections for other water uses (withdrawals) are shown to the right, together with their uncertainty ranges. Names of the bioenergy scenarios are constructed as \{author $\}$ publication year $\}-\{$ scenario name $\}$ and those of "other water use" scenarios as $\{$ author $\}$ publication year $\}-\{$ simulation year $\}$. 


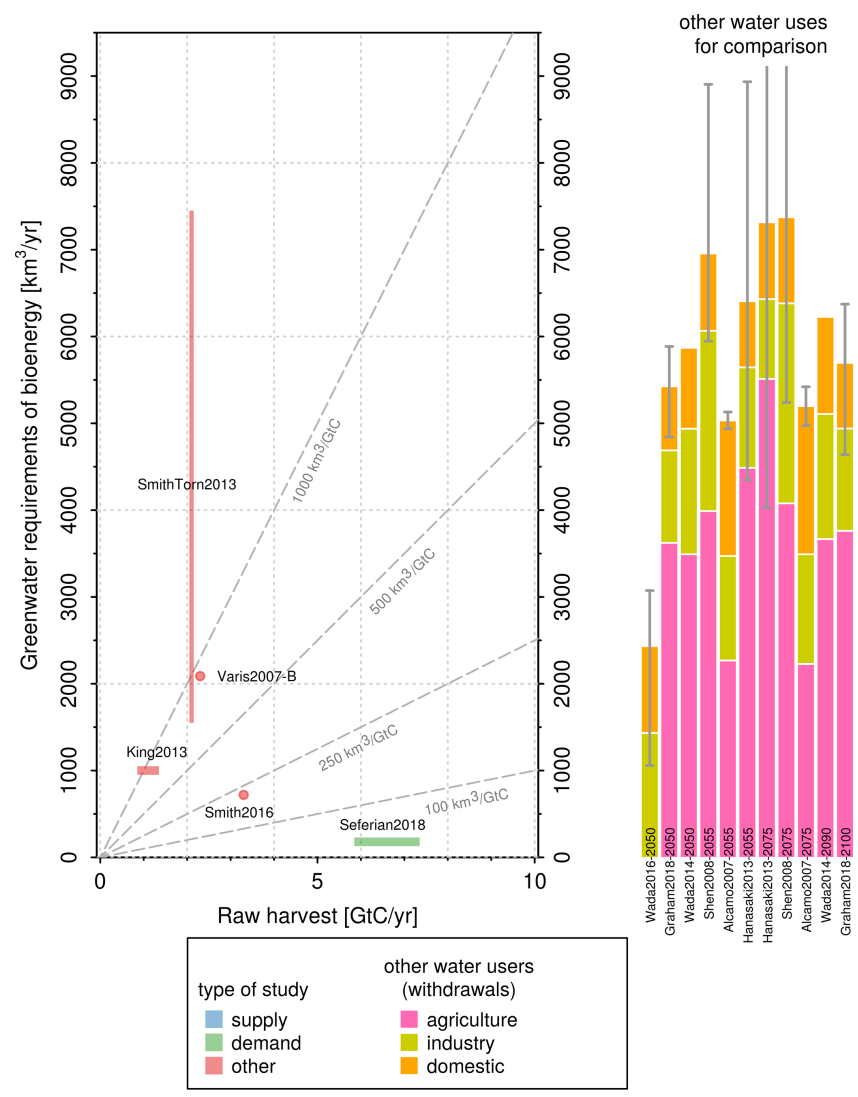

Figure A3. Analogous to Fig. 2, but for scenarios of reported global green water consumption volumes required for bioenergy production through biomass plantations. Scenarios are characterized by water consumption for bioenergy plotted against raw harvest (inferred from reported biomass based energy or negative emissions). They can provide ranges in water consumption or raw harvest (illustrated by boxes) or contain single values (depicted by circles). For contextualization, projections for other water uses (withdrawals) are shown to the right, together with their uncertainty ranges. Names of the bioenergy scenarios are constructed as \{author\} \{publication year $\}-\{$ scenario name $\}$ and those of "other water use" scenarios as \{author $\}$ \{publication year $\}-\{$ simulation year $\}$.

\section{Appendix B: List of abbreviations}

$\begin{array}{ll}\text { Description } & \\ \text { BECCS } & \text { bioenergy with carbon capture and storage } \\ \text { BP } & \text { bioenergy plantation } \\ \text { CCS } & \text { carbon capture and storage } \\ c_{\text {eff }} & \text { carbon conversion efficiency } \\ \text { DGVM } & \text { dynamic global vegetation model } \\ \text { EFR } & \text { environmental flow requirement } \\ \text { ESM } & \text { Earth system model } \\ \text { IAM } & \text { integrated assessment model } \\ \text { iwue } & \text { inverse water-use efficiency } \\ \text { NE } & \text { negative emission } \\ \text { NET } & \text { negative emission technology } \\ \text { SSP } & \text { shared socioeconomic pathway }\end{array}$


Data availability. The results from the literature analysis are available at https://doi.org/10.5880/PIK.2020.007 (Stenzel et al., 2021). Any additional data that support the findings of this study are included within the article.

Author contributions. FS designed the study and carried out the literature analysis of bioenergy-freshwater abstractions. DG contributed to the study design. NH carried out the literature analysis of the other water users. FS prepared the manuscript. DG and NH contributed to manuscript preparation.

Competing interests. The authors declare that they have no conflict of interest.

Acknowledgements. This study was funded by the CE-Land+ project of the German Research Foundation's Priority Programme DFG SPP 1689 on "Climate Engineering - Risks, Challenges and Opportunities?" Part of the research was developed during the Young Scientists Summer Program at the International Institute for Applied Systems Analysis, Laxenburg, Austria, with financial support from the German National Member Organization.

Financial support. The publication of this article was funded by the Open Access Fund of the Leibniz Association.

Review statement. This paper was edited by Nunzio Romano and reviewed by David Ellison, Mohamad Hejazi, and two anonymous referees.

\section{References}

Al-Ansari, T., Korre, A., Nie, Z., and Shah, N.: Integration of greenhouse gas control technologies within the energy, water and food nexus to enhance the environmental performance of food production systems, J. Clean. Prod., 162, 1592-1606, https://doi.org/10.1016/j.jclepro.2017.06.097, 2017.

Alcamo, J., Döll, P., Henrichs, T., Kaspar, F., Lehner, B., Rösch, T., and Siebert, S.: Global estimates of water withdrawals and availability under current and future "business-as-usual" conditions, Hydrolog. Sci. J., 48, 339348, https://doi.org/10.1623/hysj.48.3.339.45278, 2003.

Alcamo, J., Flörke, M., and Märkner, M.: Future long-term changes in global water resources driven by socio-economic and climatic changes, Hydrolog. Sci. J., 52, 247-275, 2007.

Azar, C., Lindgren, K., Larson, E., and Möllersten, K.: Carbon capture and storage from fossil fuels and biomass - Costs and potential role in stabilizing the atmosphere, Clim. Change, 74, 47-79, https://doi.org/10.1007/s10584-005-3484-7, 2006.

Bauer, N., Rose, S. K., Fujimori, S., van Vuuren, D. P., Weyant, J., Wise, M., Cui, Y., Daioglou, V., Gidden, M. J., Kato, E., Kitous, A., Leblanc, F., Sands, R., Sano, F., Strefler, J., Tsutsui, J., Bibas, R., Fricko, O., Hasegawa, T., Klein, D., Kurosawa, A., Mima, S., and Muratori, M.: Global energy sector emission reductions and bioenergy use: overview of the bioenergy demand phase of the EMF-33 model comparison, Climatic Change, 163, 1553-1568, https://doi.org/10.1007/s10584-018-2226-y, 2018.

Beringer, T., Lucht, W., and Schaphoff, S.: Bioenergy production potential of global biomass plantations under environmental and agricultural constraints, GCB Bioenergy, 3, 299-312, https://doi.org/10.1111/j.1757-1707.2010.01088.x, 2011.

Berndes, G.: Bioenergy and water - the implications of largescale bioenergy production for water use and supply, Global Environ. Chang., 12, 253-271, https://doi.org/10.1016/S09593780(02)00040-7, 2002.

Berndes, G. and Borjesson, P.: Implications of irrigation and water management for the net energy performance of bioenergy systems, Department of Physical Resource Theory, Chalmers University of Technology and Goteborg University, Goteborg, Sweden, 2001.

Bonsch, M., Humpenöder, F., Popp, A., Bodirsky, B., Dietrich, J. P., Rolinski, S., Biewald, A., Lotze-Campen, H., Weindl, I., Gerten, D., and Stevanovic, M.: Trade-offs between land and water requirements for large-scale bioenergy production, GCB Bioenergy, 8, 11-24, https://doi.org/10.1111/gcbb.12226, 2016.

Boysen, L. R., Lucht, W., Gerten, D., Heck, V., Lenton, T. M., and Schellnhuber, H. J.: The limits to global-warming mitigation by terrestrial carbon removal, Earths Future, 5, 463-474, https://doi.org/10.1002/2016EF000469, 2017.

Brosse, N., Dufour, A., Meng, X., Sun, Q., and Ragauskas, A.: Miscanthus: a fast-growing crop for biofuels and chemicals production, Biofuel. Bioprod. Bior., 6, 580-598, https://doi.org/10.1002/bbb.1353, 2012.

Calvin, K., Patel, P., Clarke, L., Asrar, G., Bond-Lamberty, B., Cui, R. Y., Di Vittorio, A., Dorheim, K., Edmonds, J., Hartin, C., Hejazi, M., Horowitz, R., Iyer, G., Kyle, P., Kim, S., Link, R., McJeon, H., Smith, S. J., Snyder, A., Waldhoff, S., and Wise, M.: GCAM v5.1: representing the linkages between energy, water, land, climate, and economic systems, Geosci. Model Dev., 12, 677-698, https://doi.org/10.5194/gmd-12-677-2019, 2019.

Campbell, J. E., Lobell, D. B., Genova, R. C., and Field, C. B.: The Global Potential of Bioenergy on Abandoned Agriculture Lands, Environ. Sci. Technol., 42, 5791-5794, https://doi.org/10.1021/es800052w, 2008.

Creutzig, F., Ravindranath, N. H., Berndes, G., Bolwig, S., Bright, R., Cherubini, F., Chum, H., Corbera, E., Delucchi, M., Faaij, A., Fargione, J., Haberl, H., Heath, G., Lucon, O., Plevin, R., Popp, A., Robledo-Abad, C., Rose, S., Smith, P., Stromman, A., Suh, S., and Masera, O.: Bioenergy and climate change mitigation: an assessment, GCB Bioenergy, 7, 916-944, https://doi.org/10.1111/gcbb.12205, 2015.

DeAngelis, A., Dominguez, F., Fan, Y., Robock, A., Kustu, M. D., and Robinson, D.: Evidence of enhanced precipitation due to irrigation over the Great Plains of the United States, J. Geophys. Res.-Atmos., 115, D15115, https://doi.org/10.1029/2010JD013892, 2010.

De Fraiture, C. and Perry, C.: Why is irrigation water demand inelastic at low price ranges, in: Conference on Irrigation Water Policies: Micro and Macro Considerations, 15-17 June 2002, Agadir, Morocco, 15-17, 2002.

De Fraiture, C., Giordano, M., and Liao, Y.: Biofuels and implications for agricultural water use: blue impacts of green energy, 
Water Policy, 10, 67-81, https://doi.org/10.2166/wp.2008.054, 2008.

Dinar, A. and Mody, J.: Irrigation water management policies: Allocation and pricing principles and implementation experience, Nat. Resour. Forum, 28, 112-122, https://doi.org/10.1111/j.1477-8947.2004.00078.x, 2004.

Ellison, D., Wang-Erlandsson, L., Van Der Ent, R., and Van Noordwijk, M.: Upwind forests: managing moisture recycling for nature-based resilience, in: Vol. 70 2019/1, edited by: Sarre, A., FAO, ISBN 978-92-5-131910-9, ISSN 0041-6436, 2019.

Fader, M., Gerten, D., Thammer, M., Heinke, J., Lotze-Campen, H., Lucht, W., and Cramer, W.: Internal and external green-blue agricultural water footprints of nations, and related water and land savings through trade, Hydrol. Earth Syst. Sci., 15, 1641-1660, https://doi.org/10.5194/hess-15-1641-2011, 2011.

Fajardy, M. and Mac Dowell, N.: Can BECCS deliver sustainable and resource efficient negative emissions?, Energ. Environ. Sci., 10, 1389-1426, https://doi.org/10.1039/C7EE00465F, 2017.

Fajardy, M., Chiquier, S., and Mac Dowell, N.: Investigating the BECCS resource nexus: delivering sustainable negative emissions, Energ. Environmen. Sci., 11, 3408-3430, https://doi.org/10.1039/C8EE01676C, 2018.

Fike, J., Parrish, D., Alwang, J., and Cundiff, J.: Challenges for deploying dedicated, large-scale, bioenergy systems in the USA, CAB Reviews: Perspectives in Agriculture, Veterinary Science, Nutrition and Natural Resources, 2, 064, https://doi.org/10.1079/PAVSNNR20072064, 2007.

Fuss, S., Lamb, W. F., Callaghan, M. W., Hilaire, J., Creutzig, F., Amann, T., Beringer, T., Garcia, W. D. O., Hartmann, J., Khanna, T., Luderer, G., Nemet, G. F., Rogelj, J., Smith, P., Vicente, J. L. V., Wilcox, J., Dominguez, M. D. M. Z., and Minx, J. C.: Negative emissions - Part 2: Costs, potentials and side effects, Environ. Res. Lett., 13, 063002, https://doi.org/10.1088/17489326/aabf9f, 2018.

Gerbens-Leenes, P. W., van Lienden, A. R., Hoekstra, A. Y., and van der Meer, T. H.: Biofuel scenarios in a water perspective: The global blue and green water footprint of road transport in 2030, Global Environ. Change, 22, 764-775, https://doi.org/10.1016/j.gloenvcha.2012.04.001, 2012.

Gerten, D., Hoff, H., Rockström, J., Jägermeyr, J., Kummu, M., and Pastor, A. V.: Towards a revised planetary boundary for consumptive freshwater use: role of environmental flow requirements, Curr. Opin. Environ. Sust., 5, 551-558, https://doi.org/10.1016/j.cosust.2013.11.001, 2013.

Gough, C. and Vaughan, N.: Synthesising existing knowledge on the feasibility of BECCS, AVOID2 Report WPD1a, available at: https://avoid-net-uk.cc.ic.ac.uk/wp-content/uploads/delightfuldownloads/2015/09/Synthesising-existing-knowledge-onfeasibility-of-BECCS (last access: 31 March 2021), 2015.

Gough, C., Garcia-Freites, S., Jones, C., Mander, S., Moore, B., Pereira, C., Röder, M., Vaughan, N., and Welfle, A.: Challenges to the use of BECCS as a keystone technology in pursuit of $1.5^{\circ} \mathrm{C}$, Global Sustainability, 1, e5, https://doi.org/10.1017/sus.2018.3, 2018.

Graham, N. T., Davies, E. G. R., Hejazi, M. I., Calvin, K., Kim, S. H., Helinski, L., Miralles-Wilhelm, F. R., Clarke, L., Kyle, P., Patel, P., Wise, M. A., and Vernon, C. R.: Water Sector Assumptions for the Shared Socioeconomic Pathways in an In- tegrated Modeling Framework, Water Resour. Res., 54, 64236440, https://doi.org/10.1029/2018WR023452, 2018.

Haberl, H., Beringer, T., Bhattacharya, S. C., Erb, K.-H., and Hoogwijk, M.: The global technical potential of bio-energy in 2050 considering sustainability constraints, Curr. Opin. Env. Sust., 2, 394-403, https://doi.org/10.1016/j.cosust.2010.10.007, 2010.

Hanasaki, N., Fujimori, S., Yamamoto, T., Yoshikawa, S., Masaki, Y., Hijioka, Y., Kainuma, M., Kanamori, Y., Masui, T., Takahashi, K., and Kanae, S.: A global water scarcity assessment under Shared Socio-economic Pathways - Part 1: Water use, Hydrol. Earth Syst. Sci., 17, 2375-2391, https://doi.org/10.5194/hess-17-2375-2013, 2013a.

Hanasaki, N., Fujimori, S., Yamamoto, T., Yoshikawa, S., Masaki, Y., Hijioka, Y., Kainuma, M., Kanamori, Y., Masui, T., Takahashi, K., and Kanae, S.: A global water scarcity assessment under Shared Socio-economic Pathways - Part 1: Water use, Hydrol. Earth Syst. Sci., 17, 2375-2391, https://doi.org/10.5194/hess-17-2375-2013, 2013 b.

Heck, V., Gerten, D., Lucht, W., and Boysen, L. R.: Is extensive terrestrial carbon dioxide removal a "green" form of geoengineering? A global modelling study, Global Planet. Change, 137, 123-130, https://doi.org/10.1016/j.gloplacha.2015.12.008, 2016.

Heck, V., Gerten, D., Lucht, W., and Popp, A.: Biomass-based negative emissions difficult to reconcile with planetary boundaries, Nat. Clim. Change, 8, 151-155, https://doi.org/10.1038/s41558017-0064-y, 2018.

Hejazi, M. I., Edmonds, J., Clarke, L., Kyle, P., Davies, E., Chaturvedi, V., Wise, M., Patel, P., Eom, J., and Calvin, K.: Integrated assessment of global water scarcity over the 21 st century under multiple climate change mitigation policies, Hydrol. Earth Syst. Sci., 18, 2859-2883, https://doi.org/10.5194/hess-18-28592014, 2014.

Hejazi, M. I., Voisin, N., Liu, L., Bramer, L. M., Fortin, D. C., Hathaway, J. E., Huang, M., Kyle, P., Leung, L. R., Li, H.-Y., Liu, Y., Patel, P. L., Pulsipher, T. C., Rice, J. S., Tesfa, T. K., Vernon, C. R., and Zhou, Y.: 21st century United States emissions mitigation could increase water stress more than the climate change it is mitigating, P. Natl. Acad. Sci. USA, 112, 10635-10640, https://doi.org/10.1073/pnas.1421675112, 2015.

Hoekstra, A., Chapagain, A., Martinez-Aldaya, M., and Mekonnen, M.: Water footprint manual: state of the art 2009, Water Footprint Network, available at: https://waterfootprint.org/media/ downloads/TheWaterFootprintAssessmentManual_2.pdf (last access: 31 March 2021), 2009.

Hoff, H., Falkenmark, M., Gerten, D., Gordon, L., Karlberg, L., and Rockström, J.: Greening the global water system, J. Hydrol., 384, 177-186, https://doi.org/10.1016/j.jhydrol.2009.06.026, 2010.

Hogan, R., Stiles, S., Tacker, P., Vories, E., and Bryant, K.: Estimating irrigation costs, Little Rock, AR: Arkansas Cooperative Extension Service. FSA28-PD-6-07RV, available at: https://www.ars.usda.gov/research/publications/publication/ ?seqNo115=210763 (last access: 31 March 2021), 2007.

Hogeboom, R., de Bruin, D., Schyns, J. F., Krol, M., and Hoekstra, A. Y.: Capping Human Water Footprints in the World's River Basins, Earths Future, 8, e2019EF001363, https://doi.org/10.1029/2019EF001363, 2020.

Hu, B., Zhang, Y., Li, Y., Teng, Y., and Yue, W.: Can bioenergy carbon capture and storage aggravate 
global water crisis?, Sci. Total Environ., 714, 136856, https://doi.org/10.1016/j.scitotenv.2020.136856, 2020.

Humpenöder, F., Popp, A., Bodirsky, B. L., Weindl, I., Biewald, A., Lotze-Campen, H., Dietrich, J. P., Klein, D., Kreidenweis, U., Müller, C., Rolinski, S., and Stevanovic, M.: Large-scale bioenergy production: how to resolve sustainability trade-offs?, Environ. Res. Lett., 13, 024011, https://doi.org/10.1088/17489326/aa9e3b, 2018.

IEA: Bioenergy - a sustainable and reliable energy source, International Energy Agency Bioenergy, Paris, France, 2009.

Jägermeyr, J., Gerten, D., Heinke, J., Schaphoff, S., Kummu, M., and Lucht, W.: Water savings potentials of irrigation systems: global simulation of processes and linkages, Hydrol. Earth Syst. Sci., 19, 3073-3091, https://doi.org/10.5194/hess-19-3073-2015, 2015.

Jans, Y., Berndes, G., Heinke, J., Lucht, W., and Gerten, D.: Biomass production in plantations: Land constraints increase dependency on irrigation water, GCB Bioenergy, 10, 628-644, https://doi.org/10.1111/gcbb.12530, 2018.

Keeney, D. and Muller, M.: Water use by ethanol plants: Potential challenges, Institute for Agriculture and Trade Policy, Minneapolis, USA, available at: https://www.iatp.org/sites/default/ files/258_2_89449.pdf (last access: 31 March 2021), 2006.

King, J. S., Ceulemans, R., Albaugh, J. M., Dillen, S. Y., Domec, J.-C., Fichot, R., Fischer, M., Leggett, Z., Sucre, E., Trnka, M., and Zenone, T.: The Challenge of Lignocellulosic Bioenergy in a Water-Limited World, BioScience, 63, 102-117, https://doi.org/10.1525/bio.2013.63.2.6, 2013.

Klein, D., Luderer, G., Kriegler, E., Strefler, J., Bauer, N., Leimbach, M., Popp, A., Dietrich, J. P., Humpenöder, F., LotzeCampen, H., and Edenhofer, O.: The value of bioenergy in low stabilization scenarios: an assessment using REMIND-MAgPIE, Clim. Change, 123, 705-718, 2014.

Klein Goldewijk, K., Beusen, A., Doelman, J., and Stehfest, E.: Anthropogenic land use estimates for the Holocene - HYDE 3.2, Earth Syst. Sci. Data, 9, 927-953, https://doi.org/10.5194/essd9-927-2017, 2017.

Krausmann, F., Erb, K.-H., Gingrich, S., Haberl, H., Bondeau, A., Gaube, V., Lauk, C., Plutzar, C., and Searchinger, T. D.: Global human appropriation of net primary production doubled in the 20th century, P. Natl. Acad. Sci. USA, 110, 10324-10329, https://doi.org/10.1073/pnas.1211349110, 2013.

Layton, K. and Ellison, D.: Induced precipitation recycling (IPR): A proposed concept for increasing precipitation through natural vegetation feedback mechanisms, Ecol. Eng., 91, 553-565, https://doi.org/10.1016/j.ecoleng.2016.02.031, 2016.

Lenton, T. M.: The potential for land-based biological $\mathrm{CO}_{2}$ removal to lower future atmospheric $\mathrm{CO}_{2}$ concentration, Carbon Manag., 1, 145-160, https://doi.org/10.4155/cmt.10.12, 2010.

Li, W., Ciais, P., Makowski, D., and Peng, S.: A global yield dataset for major lignocellulosic bioenergy crops based on field measurements, Sci. Data, 5, 180169, https://doi.org/10.1038/sdata.2018.169, 2018.

Ma, S., He, F., Tian, D., Zou, D., Yan, Z., Yang, Y., Zhou, T., Huang, K., Shen, H., and Fang, J.: Variations and determinants of carbon content in plants: a global synthesis, Biogeosciences, 15, 693702, https://doi.org/10.5194/bg-15-693-2018, 2018.

Markewitz, P., Kuckshinrichs, W., Leitner, W., Linssen, J., Zapp, P., Bongartz, R., Schreiber, A., and Müller, T. E.: Worldwide innovations in the development of carbon capture technologies and the utilization of $\mathrm{CO}_{2}$, Energy Environ. Sci., 5, 7281-7305, https://doi.org/10.1039/C2EE03403D, 2012.

Minx, J. C., Lamb, W. F., Callaghan, M. W., Fuss, S., Hilaire, J., Creutzig, F., Amann, T., Beringer, T., de Oliveira Garcia, W., Hartmann, J., Khanna, T., Lenzi, D., Luderer, G., Nemet, G. F., Rogelj, J., Smith, P., Vicente, J. L. V., Wilcox, J., and del Mar Zamora Dominguez, M.: Negative emissions - Part 1: Research landscape and synthesis, Environ. Res. Lett., 13, 063001, https://doi.org/10.1088/1748-9326/aabf9b, 2018.

Moore, N. and Rojstaczer, S.: Irrigation's influence on precipitation: Texas High Plains, U.S.A., Geophys. Res. Lett., 29, 1755, https://doi.org/10.1029/2002GL014940, 2002.

Mouratiadou, I., Biewald, A., Pehl, M., Bonsch, M., Baumstark, L., Klein, D., Popp, A., Luderer, G., and Kriegler, E.: The impact of climate change mitigation on water demand for energy and food: An integrated analysis based on the Shared Socioeconomic Pathways, Environ. Sci. Policy, 64, 48-58, https://doi.org/10.1016/j.envsci.2016.06.007, 2016.

Nakićenović, N., Grubler, A., Grübler, A., and McDonald, A.: Global energy perspectives, Cambridge University Press, Cambridge, UK, 1998.

Poff, N. L. and Zimmerman, J. K.: Ecological responses to altered flow regimes: a literature review to inform the science and management of environmental flows, Freshwater Biol., 55, 194-205, https://doi.org/10.1111/j.1365-2427.2009.02272.x, 2010.

Pokhrel, Y. N., Felfelani, F., Shin, S., Yamada, T. J., and Satoh, Y.: Modeling large-scale human alteration of land surface hydrology and climate, Geosci. Lett., 4, 1-13, https://doi.org/10.1186/s40562-017-0076-5, 2017.

Postel, S. L., Daily, G. C., and Ehrlich, P. R.: Human Appropriation of Renewable Fresh Water, Science, 271, 785-788, https://doi.org/10.1126/science.271.5250.785, 1996.

Rockström, J., Steffen, W., Noone, K., Persson, Å., Chapin, F. S., Lambin, E. F., Lenton, T. M., Scheffer, M., Folke, C., Schellnhuber, H. J., Nykvist, B., de Wit, C. A., Hughes, T., van der Leeuw, S., Rodhe, H., Sörlin, S., Snyder, P. K., Costanza, R., Svedin, U., Falkenmark, M., Karlberg, L., Corell, R. W., Fabry, V. J., Hansen, J., Walker, B., Liverman, D., Richardson, K., Crutzen, P., and Foley, J. A.: A safe operating space for humanity, Nature, 461, 472-475, https://doi.org/10.1038/461472a, 2009.

Rockström, J., Gaffney, O., Rogelj, J., Meinshausen, M., Nakicenovic, N., and Schellnhuber, H. J.: A roadmap for rapid decarbonization, Science, 355, 1269-1271, https://doi.org/10.1126/science.aah3443, 2017.

Rogelj, J., Luderer, G., Pietzcker, R. C., Kriegler, E., Schaeffer, M., Krey, V., and Riahi, K.: Energy system transformations for limiting end-of-century warming to below $1.5^{\circ} \mathrm{C}$, Nat. Clim. Change, 5, 519-527, https://doi.org/10.1038/nclimate2572, 2015.

Rogelj, J., Popp, A., Calvin, K. V., Luderer, G., Emmerling, J., Gernaat, D., Fujimori, S., Strefler, J., Hasegawa, T., and Marangoni, G.: Scenarios towards limiting global mean temperature increase below $1.5^{\circ} \mathrm{C}$, Nat. Clim. Change, 8, 325, https://doi.org/10.1038/s41558-018-0091-3, 2018.

Rosa, L., Rulli, M. C., Davis, K. F., Chiarelli, D. D., Passera, C., and D'Odorico, P.: Closing the yield gap while ensuring water sustainability, Environ. Res. Lett., 13, 104002, https://doi.org/10.1088/1748-9326/aadeef, 2018. 
Rose, S. K., Kriegler, E., Bibas, R., Calvin, K., Popp, A., van Vuuren, D. P., and Weyant, J.: Bioenergy in energy transformation and climate management, Clim. Change, 123, 477-493, https://doi.org/10.1007/s10584-013-0965-3, 2014.

Schewe, J., Heinke, J., Gerten, D., Haddeland, I., Arnell, N. W., Clark, D. B., Dankers, R., Eisner, S., Fekete, B. M., ColónGonzález, F. J., Gosling, S. N., Kim, H., Liu, X., Masaki, Y., Portmann, F. T., Satoh, Y., Stacke, T., Tang, Q., Wada, Y., Wisser, D., Albrecht, T., Frieler, K., Piontek, F., Warszawski, L., and Kabat, P.: Multimodel assessment of water scarcity under climate change, P. Natl. Acad. Sci. USA, 111, 3245-3250, https://doi.org/10.1073/pnas.1222460110, 2014.

Schlesinger, W. H. and Bernhardt, E. S.: Biogeochemistry: an analysis of global change, Academic press, available at: https://www.elsevier.com/books/biogeochemistry/schlesinger/ 978-0-12-385874-0 (last access: 31 March 2021), 1991.

Schmidt, H.-P., Anca-Couce, A., Hagemann, N., Werner, C., Gerten, D., Lucht, W., and Kammann, C.: Pyrogenic carbon capture and storage, GCB Bioenergy, 11, 573-591, https://doi.org/10.1111/gcbb.12553, 2019.

Séférian, R., Rocher, M., Guivarch, C., and Colin, J.: Constraints on biomass energy deployment in mitigation pathways: the case of water scarcity, Environ. Res. Lett., 13, 054011, https://doi.org/10.1088/1748-9326/aabcd7, 2018.

Shen, Y., Oki, T., Utsumi, N., Kanae, S., and Hanasaki, N.: Projection of future world water resources under SRES scenarios: water withdrawal/Projection des ressources en eau mondiales futures selon les scénarios du RSSE: prélèvement d'eau, Hydrolog. Sci. J., 53, 11-33, https://doi.org/10.1623/hysj.53.1.11, 2008.

Siebert, S., Kummu, M., Porkka, M., Döll, P., Ramankutty, N., and Scanlon, B. R.: A global data set of the extent of irrigated land from 1900 to 2005, Hydrol. Earth Syst. Sci., 19, 1521-1545, https://doi.org/10.5194/hess-19-1521-2015, 2015.

Smith, L. J. and Torn, M. S.: Ecological limits to terrestrial biological carbon dioxide removal, Clim. Change, 118, 89-103, https://doi.org/10.1007/s10584-012-0682-3, 2013.

Smith, P., Davis, S. J., Creutzig, F., Fuss, S., Minx, J., Gabrielle, B., Kato, E., Jackson, R. B., Cowie, A., and Kriegler, E.: Biophysical and economic limits to negative $\mathrm{CO}_{2}$ emissions, Nat. Clim. Change, 6, 42, https://doi.org/10.1038/nclimate2870, 2016.

Soccol, C. R., Brar, S. K., Faulds, C., and Ramos, L. P.: Green fuels technology: Biofuels, Springer, Switzerland, https://doi.org/10.1007/978-3-319-30205-8, 2016.

Sperna Weiland, F. C., van Beek, L. P. H., Kwadijk, J. C. J., and Bierkens, M. F. P.: The ability of a GCM-forced hydrological model to reproduce global discharge variability, Hydrol. Earth Syst. Sci., 14, 1595-1621, https://doi.org/10.5194/hess-14-15952010, 2010.

Steffen, W., Richardson, K., Rockström, J., Cornell, S. E., Fetzer, I., Bennett, E. M., Biggs, R., Carpenter, S. R., Vries, W. D., Wit, C. A. D., Folke, C., Gerten, D., Heinke, J., Mace, G. M., Persson, L. M., Ramanathan, V., Reyers, B., and Sörlin, S.: Planetary boundaries: Guiding human development on a changing planet, Science, 347, 1259855, https://doi.org/10.1126/science.1259855, 2015.

Stenzel, F., Gerten, D., Werner, C., and Jägermeyr, J.: Freshwater requirements of large-scale bioenergy plantations for limiting global warming to $1.5^{\circ} \mathrm{C}$, Environ. Res. Lett., 14, 084001, https://doi.org/10.1088/1748-9326/ab2b4b, 2019.
Stenzel, F., Hanasaki, N., and Gerten, D.: Water demand of bioenergy, GFZ Data Services, https://doi.org/10.5880/PIK.2020.007, 2021.

Tuinenburg, O. A. and Staal, A.: Tracking the global flows of atmospheric moisture and associated uncertainties, Hydrol. Earth Syst. Sci., 24, 2419-2435, https://doi.org/10.5194/hess-24-24192020, 2020.

UNFCCC, C.: Paris agreement, FCCCC/CP/2015/L. 9/Rev. 1, available at: https://unfccc.int/sites/default/files/english_paris_ agreement.pdf (last access: 30 March 2021), 2015.

Van Noordwijk, M. and Ellison, D.: Rainfall recycling needs to be considered in defining limits to the world's green water resources, P. Natl. Acad. Sci. USA, 116, 8102-8103, https://doi.org/10.1073/pnas.1903554116, 2019.

Varis, O.: Water Demands for Bioenergy Production, Int. J. Water Resour. Dev., 23, 519-535, https://doi.org/10.1080/07900620701486004, 2007.

Vervoort, R. W., Torfs, P. J. J. F., and van Ogtrop, F. F.: Irrigation increases moisture recycling and climate feedback, Australas, J. Water Resour., 13, 121-134, https://doi.org/10.1080/13241583.2009.11465367, 2009.

Vuuren, D. P. V., Edmonds, J., Kainuma, M., Riahi, K., Thomson, A., Hibbard, K., Hurtt, G. C., Kram, T., Krey, V., Lamarque, J.-F., Masui, T., Meinshausen, M., Nakicenovic, N., Smith, S. J., and Rose, S. K.: The representative concentration pathways: an overview, Climatic Change, 109, 5-31, https://doi.org/10.1007/s10584-011-0148-z, 2011.

Wada, Y. and Bierkens, M. F. P.: Sustainability of global water use: past reconstruction and future projections, Environ. Res. Lett., 9, 104003, https://doi.org/10.1088/1748-9326/9/10/104003, 2014.

Wada, Y., Gleeson, T., and Esnault, L.: Wedge approach to water stress, Nat. Geosci., 7, 615-617, https://doi.org/10.1038/ngeo2241, 2014.

Wada, Y., Flörke, M., Hanasaki, N., Eisner, S., Fischer, G., Tramberend, S., Satoh, Y., van Vliet, M. T. H., Yillia, P., Ringler, C., Burek, P., and Wiberg, D.: Modeling global water use for the 21st century: the Water Futures and Solutions (WFaS) initiative and its approaches, Geosci. Model Dev., 9, 175-222, https://doi.org/10.5194/gmd-9-175-2016, 2016.

Wang, M., Wagner, M., Miguez-Macho, G., Kamarianakis, Y., Mahalov, A., Moustaoui, M., Miller, J., VanLoocke, A., Bagley, J. E., Bernacchi, C. J., and Georgescu, M.: On the Long-Term Hydroclimatic Sustainability of Perennial Bioenergy Crop Expansion over the United States, J. Climate, 30, 2535-2557, https://doi.org/10.1175/JCLI-D-16-0610.1, 2017.

Werner, C., Schmidt, H.-P., Gerten, D., Lucht, W., and Kammann, C.: Biogeochemical potential of biomass pyrolysis systems for limiting global warming to $1.5{ }^{\circ} \mathrm{C}$, Environ. Res. Lett., 13, 044036, https://doi.org/10.1088/1748-9326/aabb0e, 2018.

Yamagata, Y., Hanasaki, N., Ito, A., Kinoshita, T., Murakami, D., and Zhou, Q.: Estimating water-food-ecosystem trade-offs for the global negative emission scenario (IPCC-RCP2.6), Sustain. Sci., 13, 301-313, https://doi.org/10.1007/s11625-017-0522-5, 2018.

Yuan, J. S., Tiller, K. H., Al-Ahmad, H., Stewart, N. R., and Stewart, C. N.: Plants to power: bioenergy to fuel the future, Trends Plant Sci., 13, 421-429, https://doi.org/10.1016/j.tplants.2008.06.001, 2008. 